\title{
FOLH1 Gene
}

National Cancer Institute

\section{Source}

National Cancer Institute. FOLH1 Gene. NCI Thesaurus. Code C38315.

This gene plays a role in folate metabolism. It is also involved in neuronal transmission. 